\title{
Renata Matusiak
}

\author{
Uniwersytet Opolski, Instytut Nauk Pedagogicznych
}

\section{Edukacja medialna we Francji}

\author{
Media education in France
}

\begin{abstract}
ABSTRAKT
Edukacja medialna stanowi ważny punkt edukacji szkolnej i całożyciowej. Po analizie literatury związanej z edukacją medialną we Francji można mówić o rozbudowanej wizji i działaniach dotyczących realizacji edukacji medialnej we Francji. Od strony praktycznej należy jednak zauważyć, że podobnie jak w Polsce, istnieją problemy $\mathrm{z}$ jej oceną, gdyż jest realizowana w ramach wielu przedmiotów. Należy zwrócić uwagę na postrzeganie edukacji medialnej we Francji jako edukacji przyszłościowej, a także na problemy trawiące jej wnętrze, jak nierównomierny dostęp do edukacji, problemy komunikacyjne i kulturowe spowodowane napływem emigrantów do dużych aglomeracji we Francji, a także wtórny analfabetyzm części potencjalnych odbiorców edukacji medialnej. W dyskusji pojawiają się także pytania dotyczące konsumpcji mediów, w tym głównie Internetu. Problemem jest też fakt, że umiejętności techniczne młodych ludzi będących częścią społeczeństwa francuskiego przewyższają rozumienie sztuki korzystania z mediów, co bardzo przypomina problem Polski w tym kontekście.
\end{abstract}

SŁOWA KLUCZOWE: edukacja medialna, edukacja medialna we Francji, kompetencje medialne.

\section{ABSTRACT}

Media education is an important point of school and lifelong education. As a result of the analysis of the literature related to media education in France, one can speak about the expanded vision and activities regarding the implementation of media education in France. From the practical point of view, however, it should be noted that, as in Poland, there are problems with its assessment, as it is implemented in many subjects. Attention should be paid to the perception of media education in France as future education, as well as problems that digest its interior, such as uneven access to education, communication and cultural problems caused by the inflow of emigrants to large agglomerations in France, as well as secondary illiteracy of some of the potential recipients of media education. Among the discussions there are also questions regarding the consumption of the media, mainly the Internet. The problem is also the fact that the technical skills of young people being part of French society will exceed the understanding of the art of using media, which reminds us very much and the problem of Poland in this context.

\section{KEYWORDS:}

media education, media education in France, media competences. 


\section{WPROWADZENIE}

Edukacja medialna to współcześnie ważny temat edukacyjno-wychowawczy. Kompetencje i umiejętności cyfrowe są elementami wymaganymi, aby funkcjonować w rzeczywistości cyberkultury i świata medialnego opartego na Internecie, który jest wielką przestrzenią w ciągłym ruchu, który implikuje jednocześnie utratę pojęcia terytorium i powstawanie mostów pomiędzy odległymi lądami. Aktywna obecność w Internecie przypomina poruszanie się po morzu - jesteśmy wszędzie i nigdzie. Przestrzeń, w której jesteśmy, jest zmienna i nie wydaje się, że mogłaby być strukturalizowana jak inne przestrzenie jakie znamy ${ }^{1}$. Internet jako popularne narzędzie komunikacji staje się przedmiotem wielu analiz, w tym też edukacji medialnej². Poznanie mediów, w tym duży nacisk kładziony na funkcjonowanie w cyberprzestrzeni powoduje, że jest to już nie wybór, a konieczność w edukacji. Taki obraz jest dostrzegany przez wszystkie kraje wysokorozwinięte, a w szczególności kraje Unii Europejskiej. Możemy wśród nich znaleźć te, które stanowią przykład dobrych praktyk w zakresie edukacji medialnej, gdyż w nich rozwój kompetencji wydaje się bardziej dynamiczny i zorganizowany, niż w pozostałych. Do takich przykładów należą Islandia ${ }^{3}$, Finlandia, Norwegia ${ }^{4}$, Wielka Brytania czy Francja ${ }^{5}$.

Jako jeden z krajów, w którym analizowana była edukacja medialna, wybrano Francję. Powodem tego było zauważenie sprzeczności związanych z realizacją edukacji medialnej. Z jednej strony praktyki francuskiej edukacji medialnej

${ }^{1}$ M.V. Rosati, S'orienter dans le virtuel, Wyd. Hermann, Paris 2012, s. 93.

${ }^{2}$ D. Bressy, Un projet pour travailler l'image et les médias, Wyd. Nord Compo, Paris 2008. D. Frau-Meigs, Socialisation des jeunes et éducation aux medias, Wyd. Eres, Toulouse 2011, S. 20.

${ }^{3}$ Zob. L. Pokrzycka, System medialny Islandii, Wyd. Wydawnictwo Uniwersytetu Marii Curie-Skłodowskiej, Lublin 2014, L. Pokrzycka, Media w Islandii. Ogólna charakterystyka, „Zeszyty prasoznawcze", t. 57, nr 3 (219), Kraków 2014, s. 507-516, L. Pokrzycka, Metody kształcenia medialnego na Islandii, „Przegląd Bałtycki”, http://przegladbaltycki.pl/2861,metody-ksztalcenia-medialnego-islandii.html, (dostęp. 8.01.2020 r.).

${ }^{4}$ Zob. L. Pokrzycka, Edukacja dziennikarska w Norwegii, „Przegląd Bałtycki”, http://przegladbaltycki.pl/3389,edukacja-dziennikarska-norwegii.html, (dostęp. 8.01.2020 r.).

${ }^{5}$ Zob. M.V. Rosati, Égarements: amour, mort et identités numériques, Wyd. Hermann, Paris 2014. M. Wieviorka, L'impératif numérique ou La nouvelle ère des sciences humaines et socials?, Wyd. CNRS editions, Paris 2013. V. Lavergne Boudier, Y. Dambach, Serious game: révolution pédagogique, Wyd. Hermes Science, Pris 2010. D. Bressy, Un projet pour travailler l'image et les médias, Wyd. Nord Compo, Paris 2008. D. Frau-Meigs, Socialisation des jeunes et éducation aux medias, Wyd. Eres, Toulouse 2011. 
pokazują, że jest ona realizowana na wysokim poziomie, o czym świadczą informacje uzyskane z badań. $\mathrm{Z}$ drugiej zaś, edukacja medialna jest zróżnicowana, jeśli chodzi o działania dla poszczególnych grup społecznych, co spowodowane jest rozbieżnościami kulturowymi i etnicznymi adresatów tych działań, co szerzej omówiono w drugiej części artykułu.

W artykule zawarto wstępną analizę edukacji medialnej we Francji, wprowadzenie do edukacji medialnej we Francji na podstawie literatury w części zdobytej podczas kwerendy bibliotecznej w paryskich bibliotekach. Celem badań było poznanie procesu realizacji edukacji medialnej we Francji. Ponadto Autorka wskazała rolę technologii w edukacji medialnej w obu krajach i skutków spowodowanych działaniami mediów, które dotykają dzieci i młodzież. Z uwagi na rozległość badań
Należy zwrócić uwagę na postrzeganie edukacji medialnej we Francji, jako edukacji przyszłościowej, a także na problemy trawiące jej wnętrze, jak nierównomierny dostęp do edukacji, problemy komunikacyjne i kulturowe spowodowane napływem emigrantów do dużych aglomeracji we Francji, a także wtórny analfabetyzm części potencjalnych odbiorców edukacji medialnej.

w tym artykule zostanie omówiony problem definicji edukacji medialnej, edukacja medialna we francuskim systemie kształcenia, polityka państwa w zakresie edukacji medialnej i wprowadzenie do problemów edukacji medialnej we Francji.

\section{ROZWAŻANIA TERMINOLOGICZNE WOKÓŁ POJĘCIA „EDUKACJA MEDIALNA"}

Dyrektywa Unii Europejskiej o audiowizualnych usługach medialnych reguluje kwestie związane z racjonalnym korzystaniem ze środków i narzędzi multimedialnych. W motywie 47 ujęte są kompetencje medialne, jednak nie ujmuje się tu 
wprost określenia edukacja medialna. Tłumaczony wprost motyw 47 określa, że „umiejętność korzystania z mediów obejmuje zdolność, wiedzę i osąd pozwalające konsumentom skutecznie i bezpiecznie korzystać z mediów. Osoby cechujące się umiejętnością korzystania z mediów potrafią dokonywać świadomych wyborów, zdają sobie sprawę z charakteru treści i usług, a także są w stanie korzystać z całego zakresu możliwości stwarzanych przez nowe technologie komunikacyjne. Umieją one lepiej chronić siebie i swoją rodzinę przed materiałami szkodliwymi lub obraźliwymi. Dlatego należy upowszechniać umiejętność korzystania z mediów we wszystkich grupach społecznych i uważnie obserwować rozwój tych umiejętności" ${ }^{6}$. W zależności od wersji językowej, w której tłumaczona jest definicja, kontekst pozostaje, jednak zmieniają się terminy określające podobne terminy. Anglojęzyczna wersja podaje w treści tego fragmentu definicję „kompetencji medialnych" (media literacy), natomiast w wersji francuskojęzycznej jest mowa o edukacji medialnej, a ujmując ściślej to twierdzenie - o „edukacji do mediów" (éducation aux média) 7 . Interesujące jest podejście Francuzów, którzy używają zwrotów do przyszłości, aby nauczyć się czegoś, co będzie im potrzebne w przyszłości. Stąd też, używane jest samo określenie: „edukacja do mediów”, czy też określenie „edukacja dla mediów”. To zauważalna potrzeba korzystania z mediów i ich rozumienia, a także ich udział w procesie życiowym i socjalizacyjnym jednostki. Wpływa to na emocje, rozumowanie, wyznawane wartości czy doświadczenia odbiorców mediów ${ }^{8}$. Z kolei, jak zostało uwidocznione powyżej, polskie tłumaczenie nie używa w ogóle żadnego z tych terminów, zasób kompetencji medialnych obejmując opisowo jako „umiejętność korzystania z mediów”.

${ }^{6}$ Motyw 47, Dyrektywa Parlamentu Europejskiego i Rady 2010/13/UE z dnia 10 marca 2010 r. w sprawie koordynacji niektórych przepisów ustawowych, wykonawczych i administracyjnych państw członkowskich dotyczacych świadczenia audiowizualnych usług medialnych (dyrektywa o audiowizualnych usługach medialnych) - wersja ujednolicona, L 95/1.

${ }^{7}$ E. Murawska-Najmiec, Organizacje międzynarodowe: edukacja medialna $w$ polityce Unii Europejskiej i UNESC, [w:] Cyfrowa przyszłość. Edukacja medialna i informacyjna w Polsce. Raport otwarcia, red. J. Lipszyc, Narodowy Instytut Audiowizualny, Fundacja Nowoczesna Polska, Warszawa 2012, s. 75, książka w wersji elektronicznej, http://nowoczesnapolska.org.pl/, data dostępu 11.01.2020 r.

${ }^{8}$ D. Frau-Meigs, Socialisation des jeunes et éducation aux medias, Wyd. Eres, Toulouse 2011, s. 7.

${ }^{9}$ E. Murawska-Najmiec, Organizacje międzynarodowe: edukacja medialna $w$ polityce Unii Europejskiej i UNESCO, [w:] Cyfrowa przyszłość..., dz. cyt. 
Literatura przedmiotowa ukazuje różne pojęcia „edukacji medialnej”, co niestety wpływa na konflikty środowisk naukowych, a przede wszystkim przekłada się na stronę pragmatyczną. Brak jednoznacznej definicji utrudnia przede wszystkim diagnozę problemów oraz podejmowanie kroków w stronę profilaktyki i przeciwdziałania negatywnym następstwom zagrożeń związanych z korzystaniem z sieci. Z jednej strony edukacja medialna w kontekście międzynarodowym obejmuje obszar pojęciowy ulegający ciągłym przeobrażeniom, z drugiej zaś modyfikacjom podlegają grupy docelowe edukacji medialnej ${ }^{10}$.

W popularnej encyklopedii mass mediów edukacja ta definiowana jest jako „(...) kierunek kształcenia, zmierzający do wyposażenia dzieci, młodzieży i osób dorosłych w określoną wiedzę i umiejętności, pozwalające na świadomy i krytyczny odbiór przekazów medialnych, w szczególności komunikatów przekazywanych przez mass media, a także na posługiwanie się mediami jako narzędziami opisywania świata, rozwoju intelektualnego i komunikowania się wzajemnego"11, natomiast $\mathrm{w}$ ujęciu Wacława Strykowskiego edukacja medialna jest procesem, który ma na celu przygotowanie do właściwego korzystania z mediów ${ }^{12}$. Krajowa Rada Radiofonii i Telewizji rozszerza tę definicję o kompetencje i umiejętności, które użytkownik mediów nabywa przez całe życie. Edukacja medialna „to proces kształtowania i upowszechniania umiejętności świadomego i krytycznego korzystania ze środków społecznego przekazu we wszystkich grupach społecznych oraz wiekowych. Proces edukacji medialnej to działania, które powinny trwać przez całe życie, ponieważ formy i technologie przekazu ulegają zmianom, a ponadto społeczeństwo także ulega ciągłym przeobrażeniom"13. Edukacja medialna jest wiodącą kompetencją, stanowiąc jednocześnie odpowiednik umiejętności czytania i pisania, a jej brak jest przesłanką do wykluczenia społecznego ${ }^{14}$.

10 Tamże, s. 75.

${ }^{11}$ J. Skrzypczak, Popularna encyklopedia mass mediów, Wydawnictwo Kurpisz, Poznań 1999 , s. 117.

${ }^{12}$ W. Strykowski, Media i edukacja medialna $w$ tworzeniu współczesnego społeczeństwa, [w:] Media i edukacja $w$ dobie integracji, red. W. Strykowski, W. Skrzydlewski, Wydawnictwo eMPi2, Poznań 2002, s. 19.

${ }^{13}$ A. J. Dąbrowska, P. Drzewiecki, J. Jasiewicz, J. Lipszyc, G. D. Stunża, Konwergencja kompetencji - definicja edukacji medialnej i informacyjnej, [w:] Cyfrowa przyszłość..., s. 10.

${ }^{14}$ E. Murawska-Najmiec, Organizacje międzynarodowe: edukacja medialna w polityce Unii Europejskiej i UNESCO, [w:] Cyfrowa przyszłość..., s. 12. 
W języku francuskim termin „edukacja medialna” jest rozpatrywany jako „edukacja do mediów”, co jednoznacznie wskazuje na zawężenie tego pojęcia tylko do jednego ze składników edukacji medialnej. Obok edukacji do mediów, edukację medialną rozpatruje się jeszcze w odniesieniu do edukacji poprzez media oraz edukacji o mediach. W rozważaniach terminologicznych należy jednak uwzględnić pełny kontekst oraz wieloaspektowy wymiar edukacji medialnej, która odwołuje się do tego, co jest najistotniejsze, czyli podobnie jak w polskim systemie - wychowania do odbioru mediów. Tak rozumiane wychowanie jest efektem kształcenia w zakresie wszystkich trzech komponentów, poprzez media i do odbioru mediów ${ }^{15}$.

\section{EDUKACJA MEDIALNA WE FRANCUSKIM SYSTEMIE KSZTALCENIA}

W świetle przepisów regulujących system kształcenia we Francji edukacja mająca na celu opanowanie technologii informacyjno-komunikacyjnych jest czwartym $\mathrm{z}$ siedmiu filarów podstawy programowej ${ }^{16}$. Ponadto edukacja medialna znalazła swoje zastosowanie $\mathrm{w}$ podstawie programowej w filarze szóstym dotyczącym kompetencji społecznych i obywatelskich. Jednym z jego umiejętności jest bycie wyedukowanym do mediów, bycie świadomym miejsca, które media zajmują wśród społeczeństwa, a także wpływu na społeczeństwo ${ }^{17}$. Sama edukacja medialna nie stanowi odrębnego obowiązkowego przedmiotu na żadnym z etapów kształcenia, podobnie jak w polskim systemie edukacji, kompetencje medialne są nabywane w ramach innych przedmiotów kierunkowych oraz różnych inicjatyw w środowisku pozaszkolnym. W procesie kształcenia dominuje interdyscyplinarny charakter nauczania treści z zakresu tej dziedziny, starsi uczniowie zdający maturę humanistyczną mogą ją opcjonalnie wybrać z zakresu kształcenia w ramach zajęć filmowych (audiowizualnych).

Francuski system kształcenia kładzie nacisk na kształtowanie nie tylko w zakresie wiedzy, postaw, ale również umiejętności, którymi musi wykazać się uczeń będących efektem interdyscyplinarnego przyswajania treści z zakresu edukacji

${ }^{15}$ E. Murawska-Najmiec, Francja: instytucje publiczne liderem edukacji medialnej, [w:] Cyfrowa przyszłość..., $s .159$, data dostępu 10.01.2020 r.

${ }^{16}$ Dekret nr 2006-830 z dn. 11 lipca 2006 r. ws. podstawy programowej, Décret n 2006830 du 11 juillet 2006 relatif au socle commun de connaissances et de compétences et modifiant le code de l'éducation.

${ }^{17}$ E. Murawska-Najmiec, Francja: instytucje publiczne liderem edukacji medialnej, [w:] Cyfrowa przyszłość..., s. 159-160, data dostępu 10.01.2020 r. 
medialnej i kompetencji informacyjno-komunikacyjnych. Nabywanie tych kompetencji jest certyfikowane na każdym z poziomów nauczania poprzez wydawanie stosownych dokumentów na każdym etapie kształcenia. Odrębny certyfikat „B2i” dostają uczniowie na poziomie szkoły podstawowej, gimnazjum oraz szkoły średniej. Taka polityka umożliwia w sposób sformalizowany określenie kompetencji medialnych potencjalnego użytkownika wirtualnej przestrzeni. Z uwagi na wieloaspektowy charakter kształcenia i jego interdyscyplinarność ma to zdecydowany wpływ na dalsze kształtowanie obszarów pod kątem racjonalnego przy-

\section{Francuski system kształcenia kładzie nacisk na kształtowanie nie tylko w zakresie wiedzy, postaw, ale również umiejętności, którymi musi wykazać się uczeń będących efektem interdyscyplinarnego przyswajania treści z zakresu edukacji medialnej i kompetencji informacyjno-komunikacyjnych.}

gotowania do odbioru rzeczywistości cyfrowej. Zdobycie certyfikatu na każdym z trzech etapów kształcenia wyposaża bowiem użytkownika Sieci w następujące kategorie:

a) wiedza (w której znajdują się komponenty dotyczące edukacji medialnej w szerokim tego słowa znaczeniu, uwzględniające nabycie świadomości związanej z tym, iż korzystanie z nowoczesnych kompetencji wiąże się $\mathrm{z}$ ochroną nie tylko samego siebie, ale i własności intelektualnej każdego człowieka, a także reguły dotyczące praw i obowiązków obywatelskich w tym zakresie),

b) postawa (ta kategoria warunkuje posiadanie świadomości i krytycyzmu wobec pozyskiwania i przetwarzania informacji, a także wykorzystywania ich na różnych poziomach życia oraz używania przy tym narzędzi interaktywnych), 
c) umiejętności (z zakresu obsługi nowoczesnych narzędzi technologicznych) ${ }^{18}$.

Certyfikowanie tych umiejętności zapewniło władzom francuskim przełożenie na pragmatyczne zastosowanie. Nie chodzi bowiem tu o umiejętności z zakresu korzystania i technicznych umiejętności, świadczy natomiast o luce poznawczej dotyczącej treści merytorycznych w zakresie kompetencji medialnych. Francuzi są świadomi wyższych umiejętności technologicznych swoich dzieci, zauważając przy tym jednocześnie szereg niebezpieczeństw związanych z treściami przekazywanymi w tym procesie.

Istotną rolę we wspieraniu francuskiej edukacji do mediów pełni Centre de Liaison d'Enseignement et des Medias d'Information - w dosłownym tłumaczeniu oznaczające Centrum Łączności Oświaty z Mediami Informacyjnymi. CLEMI zostało założone w 1983 roku i działa pod patronatem Ministerstwa Edukacji Narodowej we Francji jako resort Krajowego Centrum Dokumentacji Pedagogicznej. Celem centrum jest wspieranie i propagowanie prawidłowo rozumianej edukacji medialnej wśród uczniów poprzez wyposażanie ich w narzędzia adekwatne do rzeczywistych wymagań. Są to umiejętności, które uczynią uczniów „(...) kompetentnymi w odczytywaniu i odszyfrowywaniu informacji oraz obrazów, wyostrzą ich krytyczne myślenie i w końcu nauczą ich jak formułować i wyrażać własne opinie w odpowiedzialny sposób"19. W znaczący sposób działania tego resortu wpływają na pogłębienie współpracy z pedagogami i nauczycielami a osobami zajmującymi się w sposób profesjonalny mediami informacyjnymi ${ }^{20}$. Zasadniczo wpływa to nie tylko na kształtowanie świadomości medialnej uczniów, ale również przygotowuje pod względem merytorycznym środowiska pedagogów do przekazywania istotnej wiedzy w procesie kształcenia na wszystkich poziomach edukacji.

Działania Centrum mają na celu nie tylko określanie teoretycznych ram programowych skierowanych do realizacji w szkołach w postaci nowej podstawy programowej uwzględniającej kontekst edukacji do mediów, jak i przez media. Poprzez realizację swoich celów na płaszczyźnie regionalnej, jak i ogólnokrajowej,

18 Tamże, s. 160.

${ }^{19}$ Edukacja medialna - nauka cyfrowego abc, https://www.schooleducationgateway.eu/ $\mathrm{pl} / \mathrm{pub} /$ latest/practices/media-literacy--the-digital-a.htm, data dostępu 01.01.2020 r.

${ }^{20}$ M. Borkowska, E. Maurawska-Najmiec, P. Stępka, A. Woźniak, Analiza Biura KRRiT, „Organizacje międzynarodowe i wybrane państwa europejskie wobec edukacji medialne”, Biuro Krajowej Rady Radiofonii i Telewizji, nr 2/2010, s. 12. 
CLEMI poprzez sieć przedstawicieli przy kuratoriach oświaty, realizuje szkolenia dla nauczycieli, wspierając ich działalność w zakresie edukacji medialnej w sposób formacyjny. Organizując szkolenia, przygotowując materiały i narzędzia, moduły i programy pilotażowe aktywnie wpisuje się w realizację wytycznych z zakresu polityki medialnej Francji. Ważne są również działania skupione wokół działalności wydawniczej związanej z realizacją naczelnych zadań statutowych oraz wydarzeniami dotyczącymi szeroko rozumianej edukacji medialnej. Wydawnictwa to głównie publikacje książkowe, prace naukowo-badawcze, specjalistyczne periodyki oraz artykuły dotyczące historii, funkcjonowania i ekonomii mediów, socjologii mediów, działu „Młodzi a media”, analizy treści oraz analizy obrazu ruchomego i nieruchomego, a także dziennikarstwa i technik dziennikarskich oraz reklamy i Internetu, rewolucji cyfrowej i edukacji medialnej oraz pomocy dydaktycznych w tym zakresie ${ }^{21}$.

Wszystkie te działania skupiają się wokół bardzo ważnego aspektu umiejętności cyfrowych, jakim jest „(...) podnoszenie świadomości w zakresie niebezpieczeństw, jakie niesie ze sobą korzystanie z Internetu"22. Praca Centrum jest skoordynowana wokół jednolitych działań w całym kraju. Oprócz działalności mającej na celu podnoszenie kompetencji i ulepszanie warsztatu racy nauczycieli, CLEMI organizuje różnego rodzaju szkolenia i konferencje dla uczniów, które pozwalają poznać świat i kulturę mediów oraz związane z nim wyzwania.

\section{POLITYKA PAŃSTWA W ZAKRESIE EDUKACJI MEDIALNEJ}

Polityka państwowa w zakresie edukacji medialnej jest aktywnie wspierana poprzez powołaną przez rząd Komisję do Spraw Rodziny i Edukacji Medialnej. Poprzez rekomendacje w raporcie pt. „Stworzenie strukturalnej polityki w zakresie edukacji do mediów przeznaczonej dla wszystkich odbiorców" zalecane zostały następujące zadania:

a) nadanie edukacji medialnej statusu przedmiotu obowiązkowego, włączając $\mathrm{w}$ ten proces wszystkie etapy nauczania razem $\mathrm{z}$ elementarnym nauczaniem edukacji medialnej już w przedszkolu,

${ }^{21}$ Tamże, s. 12-13.

${ }^{22}$ https://www.schooleducationgateway.eu/pl/pub/latest/practices/media-literacy--the-digital-a.htm, data dostępu 10.01.2020 r. 
b) zwiększona współpraca szkoły z rodzicami w zakresie edukacji medialnej, np. poprzez utworzenie różnych inicjatyw, organizację w szkole „Dnia Rodziny i Mediów",

c) zwiększona aktywność w zakresie prowadzenia badań naukowych z zakresu edukacji medialnej,

d) utworzenie kierunku studiów wyższych oferującego kształcenie kadry specjalistycznej w zakresie edukacji medialnej,

e) motywowanie młodzieży ze szkół średnich poprzez różne formy aktywności do roli twórców mediów ${ }^{23}$.

Francja jako państwo mające etatystyczne tradycje związane z charakterem państwa, projektuje działania systemowe w zakresie edukacji medialnej. Mimo to Conseil supérieur de l'audiovisuel (CSA), organ regulacyjny do spraw audiowizualnych, nie odgrywa w tym procesie istotniejszej roli2 ${ }^{24}$. Również z uwagi na dominującą rolę państwa w kształtowaniu postaw i świadomości społecznej inicjatywy społeczne nie cieszą się dużą popularnością, zarówno ze względu na zasięg, charakter działań i całokształt przedsięwzięcia. Mimo to, znacznie więcej inicjatyw obserwuje się $\mathrm{w}$ zakresie działań związanych $\mathrm{z}$ bezpieczeństwem w Sieci oraz ochroną konsumentów w czasie korzystania z Internetu. Wśród najbardziej znanych organizacji działających na rzecz upowszechnienia edukacji medialnej można wymienić:

a) CIEM (powstały w 2002 roku) - Collectif Interassociatif Enfance et Media, w dosłownym brzmieniu „Międzystowarzyszeniowy Kolektyw na rzecz Dzieciństwa i Mediów",

b) APTE - Les écrans, les médias et nous, tłumacząc dosłownie „Ekrany, media i my",

c) organizacje walczące przeciwko agresji medialnej oraz w obronie praw obywateli. Są to R.A.P - Association Résistance à l'Aggression Publicitaire, tj. „Stowarzyszenie Oporu przeciwko Agresji Reklamowej” oraz Casseurs de $\mathrm{Pu}$ - „Pogromcy Reklamy”25.

${ }^{23}$ M. Borkowska, E. Maurawska-Najmiec, P. Stępka, A. Woźniak, Analiza Biura KRRiT, „Organizacje międzynarodowe i wybrane państwa europejskie wobec edukacji medialne”, Biuro Krajowej Rady Radiofonii i Telewizji, nr 2/2010, s. 14.

${ }^{24}$ Tamże, s. 10.

${ }^{25}$ E. Murawska-Najmiec, Francja: instytucje publiczne liderem edukacji medialnej, [w:] Cyfrowa przyszłość..., s. 164, data dostępu 01.01.2020 r. 
Francja korzysta również z regulacji związanych z przynależnością do Unii Europejskiej oraz dokumentów UNESCO. Regulacje te pozwalają na urzeczywistnianie ogólnej polityki europejskiej na rzecz mieszkańców Francji, całej Europy i świata. Polityka wewnętrzna w zakresie regulacji edukacji medialnej wciąż jeszcze skłania się raczej ku dbaniu o bezpieczne korzystanie użytkowników z zasobów świata wirtualnego oraz nowoczesnych technologii multimedialnych. Edukacja medialna, a w zasadzie edukacja do mediów, jest dość powszechnym tematem, ale jak się okazuje wciąż jeszcze niesformalizowanym. Temat ten podejmowany jest w wielu publikacjach oraz badaniach naukowych, co zdecydowanie w przyszłości przełożyć się może na działalność ściśle praktyczną, nastawioną na realizację celów z zakresu edukacji medialnej.

\section{INTERNET A EDUKACJA MEDIALNA - KONSUMPCJA I NAUKA}

Podstawowe pytanie, które zadaje Bressy, dotyczy tego, czy człowiek konsumuje media, czy się uczy się z nich, o nich, dzięki nim (w szczególności dotyczy to Internetu)? Internet ma związek z edukacją. W zasadzie to jedno z głównych mediów, które wkroczyło do szkoły i na które jest zapotrzebowanie. Postrzegane już uprzednio jako instytucjonalne (wykorzystywane w instytucjach państwowych) wkroczyło także do instytucji oświatowo-wychowawczych, czyli szkół w sposób istotny. W szczególności należy podkreślić wykorzystanie Internetu w szkole nie tylko do celów edukacyjnych, ale i komunikacyjnych ${ }^{26}$.

Można zauważyć, że w Internecie pojawiają się podobne treści, jak w kanałach telewizyjnych lub radiu, czyli reklamy, materiały publicystyczne itp. Sieć natomiast stanowi podtrzymanie powiązań pomiędzy reklamą, informacją a kulturą. Informacja jest głównym priorytetem w korzystaniu z cyberprzestrzeni - szybkość dostępu i aktualność stanowią klucz do popularności wykorzystania tego medium. Można postawić pytanie, na czym polega konsumowanie mediów w kontekście edukacji medialnej? Badacz odpowiada, że na bezkrytycznym przyswajaniu treści przez dzieci, także przez wszystkich odbiorców. Dzieci więc nie oglądają emisji przeznaczonych dla swoich kategorii wiekowych, a wszystkie przekazy, które są nadawane w chwili, w jakiej oglądają telewizję czy korzystają

${ }^{26}$ D. Bressy, Un projet pour travailler l'image et les médias, Wyd. Nord Compo, Paris 2008, s. 19. 
z Internetu. Konsumpcja treści i informacji bez podziału na jakość w przypadku dzieci jest szkodliwa wychowawczo, gdyż dziecko przyswaja elementy kultury bez zrozumienia kontekstu całości, zdobywa informacje na temat fragmentów kultury. Wiedza informacyjna w ten sposób może zaszkodzić, gdyż wykracza poza wiek dziecka, a także jego zdolności zrozumienia obrazu, tekstu, zdarzeń itd. ${ }^{27}$ Brak tu miejsca na relację z kulturą, gdyż strzępy informacji nie stanowią całości jej obrazu, a więc i nie mogą być prawidłowym nośnikiem informacji o kulturze. Berssy podkreśla, że owe strzępy informacji są wymieniane pomiędzy rówieśnikami bez udziału osób dorosłych, które mogłyby przybliżyć całość przyswajanych treści, czy wytłumaczyć konteksty zdarzeń. Internet pełni dla dzieci swego rodzaju rolę okna-obrazu na rzeczywistość, tymczasem złudne jest ufać, że poprzez monitor jesteśmy w stanie zobaczyć świat w taki sposób, jakbyśmy tam byli, czyli

\section{Media podlegają człowiekowi. To media są stworzone dla człowieka, a nie człowiek dla mediów. Człowiek ma za zadanie panować nad mediami, stąd też cała idea edukacji medialnej.}

odbierać świat i zdarzeń w taki sposób, jakbyśmy w nich uczestniczyli. Rola edukacji medialnej polega na tym, że należy zmodyfikować naukę korzystania z Internetu. Nie wystarczy tylko korzystać, uczyć umiejętności, ale poprzez komentarze, opinie uczyć możliwości odrzucenia treści, zrozumienia treści osadzonej w konkretnej sytuacji. Zadaniem edukacji, nauki medialnej jest umiejętność wykorzystania danej treści w sposób odpowiedzialny i efektywny. Dzieci bardzo szybko dostrzegają pojawiające się przekazy, treści, ale sposób ich zrozumienia polega na skutecznie realizowanej edukacji medialnej ${ }^{28}$.

${ }^{27}$ Tamże, s. 19-21.

${ }^{28}$ Tamże, s. 22. 


\section{ZAKOŃCZENIE}

Badacze francuscy edukacji związanej z mediami stoją na stanowisku, że media podlegają człowiekowi. To media są stworzone dla człowieka, a nie człowiek dla mediów. Człowiek ma za zadanie panować nad mediami, stąd też cała idea edukacji medialnej. Edukacja medialna to proces, a jednocześnie rozwiązanie długofalowe. Nie opiera się tylko na „edukacji do korzystania z Internetu”, czy jakby ujęli to Francuzi „edukacji dla korzystania z Internetu”, ale obejmuje też cały szereg innych mediów, np. edukację filmową. Jednak mocno osadzona jest w zmierzaniu ku rozwojowi sektorów publicznego, prywatnego i cywilnego ${ }^{29}$, które opierają się na nowych technologiach. Dlatego też, wymaga rozwoju, bo stanowi element przyszłości ${ }^{30}$. Wśród tych teoretycznych założeń w środowisku Francji zauważalne są nierówności w edukacji medialnej - szczególnie w dużych aglomeracjach miejskich, co jest spowodowane napływem emigrantów, którzy zaczynają stanowić liczącą się grupę w większych miastach. Edukacja medialna napotyka w takich przypadkach duże trudności w adaptacji, a także nieznajomość technologiczną w zależności od grupy. Francuski rząd wprawdzie podejmuje próby niwelowania takich trudności realizując dodatkowe programy edukacyjne skierowane do imigrantów. Trudno mówić o efektach, gdyż sytuacja ulega pogłębieniu z uwagi na zmieniającą się strukturę społeczną i zwiększającą się liczbę ludności napływowej. Inna kwestia, że we Francji, podobnie jak w Polsce, edukacja medialna to edukacja pozyskiwana na różnych przedmiotach szkolnych, więc od strony praktycznej czyni ją to trudną, jeśli chodzi o dogłębną analizę i ocenę co do efektów i ścieżki edukacjii ${ }^{31}$.

\section{BIBLIOGRAFIA}

Borkowska M., E. Maurawska-Najmiec E., Stępka P., Woźniak A., Analiza Biura KRRiT, Organizacje międzynarodowe i wybrane państwa europejskie wobec edukacji medialne, Biuro Krajowej Rady Radiofonii i Telewizji, nr 2/2010.

Bressy D., Un projet pour travailler l'image et les médias, Wyd. Nord Compo, Paris 2008.

${ }^{29}$ D. Frau-Meigs, Socialisation des jeunes et éducation aux medias, Wyd. Eres, Toulouse 2011, s. 161-176.

${ }^{30}$ Tamże, s. 37.

${ }^{31}$ Tamże, s. 182. 
Dąbrowska A., Drzewiecki P., Jasiewicz J., Lipszyc J., Stunża G. D., Konwergencja kompetencji - definicja edukacji medialnej i informacyjnej, [w:] Cyfrowa przyszłość. Edukacja medialna i informacyjna $w$ Polsce. Raport otwarcia, red. J. Lipszyc, Narodowy Instytut Audiowizualny, Fundacja Nowoczesna Polska, Warszawa 2012.

Dekret nr 2006-830 z dn. 11 lipca 2006 r. ws. podstawy programowej, Décret n 2006$830 \mathrm{du} 11$ juillet 2006 relatif au socle commun de connaissances et de compétences et modifiant le code de l'éducation.

Edukacja medialna - nauka cyfrowego abc, https://www.schooleducationgateway.eu/pl/ pub/latest/practices/media-literacy--the-digital-a.htm

Frau-Meigs D., Socialisation des jeunes et éducation aux medias, Wyd. Eres, Toulouse 2011.

Lavergne Boudier V., Dambach Y., Serious game: révolution pédagogique, Wyd. Hermes Science, Paris 2010.

Motyw 47, Dyrektywa Parlamentu Europejskiego i Rady 2010/13/UE z dnia 10 marca 2010 r. $w$ sprawie koordynacji niektórych przepisów ustawowych, wykonawczych i administracyjnych państw członkowskich dotyczacych świadczenia audiowizualnych usług medialnych (dyrektywa o audiowizualnych usługach medialnych) - wersja ujednolicona, L 95/1.

Murawska-Najmiec E., Francja: instytucje publiczne liderem edukacji medialnej, [w:] Cyfrowa przyszłość. Edukacja medialna i informacyjna $w$ Polsce. Raport otwarcia, red. J. Lipszyc, Narodowy Instytut Audiowizualny, Fundacja Nowoczesna Polska, Warszawa 2012.

Murawska-Najmiec E., Organizacje międzynarodowe: edukacja medialna $w$ polityce Unii Europejskiej i UNESC [w:] Cyfrowa przyszłość. Edukacja medialna i informacyjna w Polsce. Raport otwarcia, red. J. Lipszyc, Narodowy Instytut Audiowizualny, Fundacja Nowoczesna Polska, Warszawa 2012.

Pokrzycka L., Edukacja dziennikarska w Norwegii, „Przegląd Bałtycki”, http://przegladbaltycki.pl/3389,edukacja-dziennikarska-norwegii.html

Pokrzycka L., Media w Islandii. Ogólna charakterystyka, „Zeszyty prasoznawcze”, t.57, nr 3 (219), Kraków 2014, s. 507-516.

Pokrzycka L., Metody kształcenia medialnego na Islandii, „Przegląd Bałtycki”, http://przegladbaltycki.pl/2861,metody-ksztalcenia-medialnego-islandii.html

Pokrzycka L., System medialny Islandii, Wyd. Wydawnictwo Uniwersytetu Marii Curie-Skłodowskiej, Lublin 2014.

Skrzypczak J., Popularna encyklopedia mass mediów, Wydawnictwo Kurpisz, Poznań 1999. Strykowski W., Media i edukacja medialna w tworzeniu współczesnego społeczeństwa, [w:] Media i edukacja $w$ dobie integracji, red. W. Strykowski, W. Skrzydlewski, Wydawnictwo eMPi2, Poznań 2002.

Rosati M.V., S'orienter dans le virtuel, Wyd. Hermann, Paris 2012.

Rosati M.V., Égarements: amour, mort et identités numériques, Wyd. Hermann, Paris 2014.

Wieviorka M., L'impératif numérique ou La nouvelle ère des sciences humaines et socials?, Wyd. CNRS editions, Paris 2013. 


\section{Biogram}

Renata Matusiak (Uniwersytet Opolski) - doktor nauk społecznych w zakresie pedagogiki. W ramach zainteresowań naukowych odbyła studia podyplomowe: Kryminologia z elementami profilaktyki przestępczości, Profilaktyka społeczna i terapia uzależnień, Przygotowanie pedagogiczne. Autorka kilkunastu artykułów naukowych, przewodnicząca komitetów organizacyjnych i uczestniczka licznych konferencji o zasięgu międzynarodowym i ogólnopolskim, redaktorka monografii naukowych, organizatorka i prowadząca spotkania profilaktyczne dla dzieci i młodzieży. Specjalizuje się profilaktyce społecznej i szkolnej, problematyce mediów w wychowaniu.

e-mail: renatamatusiak@poczta.onet.eu

ORCID: 0000-0001-7035-4443 